\title{
Women in the cabinet
}

The role of women in the history of science has long been overlooked.

\section{Pandora's Breeches: Women, Science and Power in the \\ Enlightenment \\ by Patricia Fara \\ Pimlico: 2004. 288 pp. $£ 12.50$ \\ Jessica Riskin}

Historians of science have been expanding their cast of characters beyond European male élites to include women, non-Europeans and members of the less-privileged classes. A second recent tendency has been to consider scientific ideas as inextricable parts of the social and cultural world in which they are generated. Pandora's Breeches gracefully straddles both movements. Patricia Fara's tactic in this elegant book is to use each of these approaches in the service of the other. Following female protagonists into the world of science during the Enlightenment, Fara enters its social and institutional dimensions, engaging in interpretation, translation and popularization. By focusing on these collective and communicative aspects of scientific work, she uncovers the main areas in which women were central to the pursuit of science.

Beyond their social and institutional roles, women occupied another niche, too. Early modern science involved much collecting and classifying, for which female assistants were often responsible. Pandora's Breeches takes a theme from this phenomenon, presenting itself as a sort of cabinet, a collection of women involved in the sciences. To the taxonomically inclined, a collection irresistibly invites classification, so here is my proposed taxonomy of the book's protagonists.

First come the inspirers: the correspondents and interlocutors. They include Elisabeth of Bohemia, who challenged Descartes to explain how immaterial soul and physical body can interact. There is Elisabeth's niece, Sophie Charlotte, Queen of Prussia, who pressed Leibniz on the problem of evil. And we have Anne Conway, whose theory of the intermingling of spirit and matter, worked out in correspondence with the Cambridge philosopher Henry More, helped shape Leibniz's ontology.

Next are the promulgators: the translators, commentators, illustrators and popularizers. Here we find Emilie du Châtelet, who translated Newton's Principia into French and wrote extensively on newtonian philosophy and its rivals, helping create a tradition of French newtonianism. There is Priscilla Wakefield, whose Introduction to Botany, which presented the linnaean system to women, became a standard text. And let us

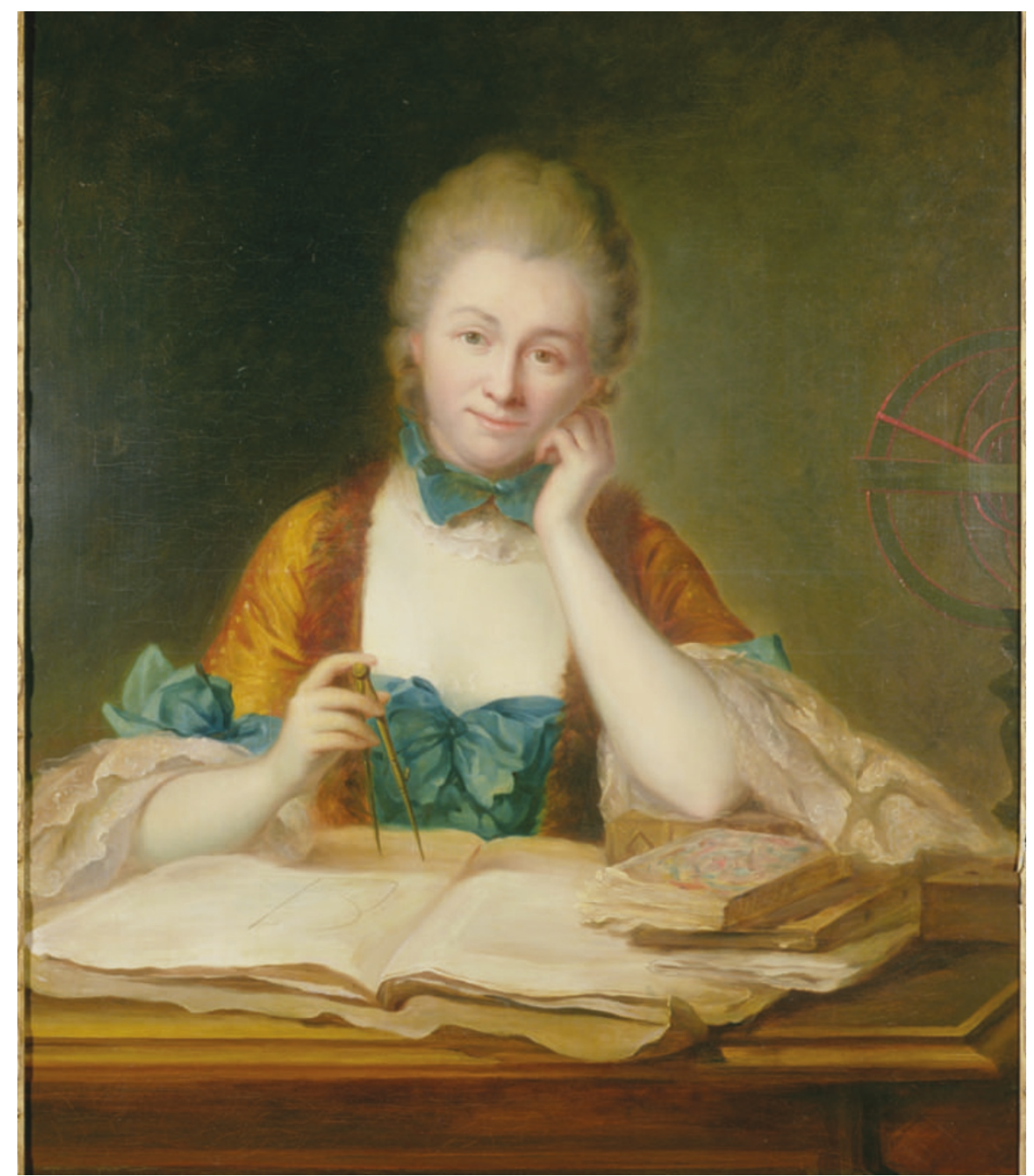

Joining forces: Emilie du Châtelet spread Newton's ideas by translating Principia into French.

not forget Marie Paulze Lavoisier, who illustrated the chemistry texts of her husband, Antoine Lavoisier.

But Paulze Lavoisier belongs equally on several other shelves. For example, she should be among the assistants, having worked in Lavoisier's laboratory. Here she is accompanied by Elisabetha Hevelius, who conducted astronomical observations with her husband, Johannes Hevelius. The importance of her collaboration is signalled by the instruments they used, which included a sextant that required two people to operate it.

Finally, we have the institution-builders. Again we find Paulze Lavoisier, who hosted a weekly salon where people discussed scientific matters along with other gossip. She also oversaw Lavoisier's household. Fara compellingly argues that when experimentation took place in private houses, the wives who ran these houses played the role of laboratory managers. In this way, Jane Dee managed
John Dee's astrological and alchemical workshops and his staff of assistants.

How shall we classify Mary Shelley? Fara presents her as a commentator and critic, and views Frankenstein as a response to contemporary debates about the nature of life and a warning against the dangers of unbridled experimentalism. These are conspicuously peripheral roles compared with the other figures' scientific activities.

At the opposite end of the spectrum sits another member in a category of her own. Caroline Herschel conducted astronomical observations both with her brother, William Herschel, and also independently. They built massive, powerful telescopes and methodically charted the stars, an enormous labour of observation, calculation and classification. Caroline's own work yielded eight comets and several nebulae and star clusters. She published in the Philosophical Transactions of the Royal Society and gained 
an international reputation, becoming an honorary member of the Royal Astronomical Society, winning various awards, and earning a salary from King George III. An astronomer in her own right, she stands out among the inspirers, promulgators, assistants and institution-builders.

The implications of any collection are best revealed by the entries that are hardest to classify. Shelley and Herschel, from opposite extremes, indicate the risks of including women by fundamentally transforming the story. Fara urges us to stop telling heroic tales of individual brilliance and show the sciences in their true light, as cooperative projects. To be sure, geniuses have never been 'lone'. But we risk confirming the traditional view that women are capable of collaboration but not brilliance. Does Jane Dee, who oversaw her husband's household, belong in the same collection as Emilie du Châtelet, one of only a handful of people in her generation capable of understanding Newton's Principia?

In other words, does this collection implicitly confirm that modern science is fundamentally a masculine philosophy and rationalism the attribute of masculinity? Or is there a different interpretation? Perusing this rich, beautifully crafted book you realize that, assuming that the sciences require both individual insight and community, even when women were continually assigned the latter, they often contributed the former. Jessica Riskin is in the Department of History, Stanford University, Stanford, California 943052024, USA.

\section{Big-game theory}

\section{The Kruger Experience: Ecology and Management of Savanna Heterogeneity}

edited by Johan T. du Toit, Kevin H. Rogers \& Harry C. Biggs

Island Press: 2003. 492 pp. $\$ 75$ (hbk), $\$ 40$ (pbk)

\section{Andrew Illius}

The Kruger National Park, a strip of bush $60 \mathrm{~km}$ wide that stretches $350 \mathrm{~km}$ from the tropical northern end of South Africa bordering Zimbabwe and Mozambique to the temperate south, is one of the world's great wildlife reserves. The Kruger Experience is not about the experience of being there, which is breathtaking, but about the accumulated experience of the managers and scientists who have worked for a century to conserve and understand it in all its glory. The editors faced the challenge of bringing together more than a hundred researchers and getting them to put their work into a common theoretical framework. The chosen 'cross-cutting theme' is ecological

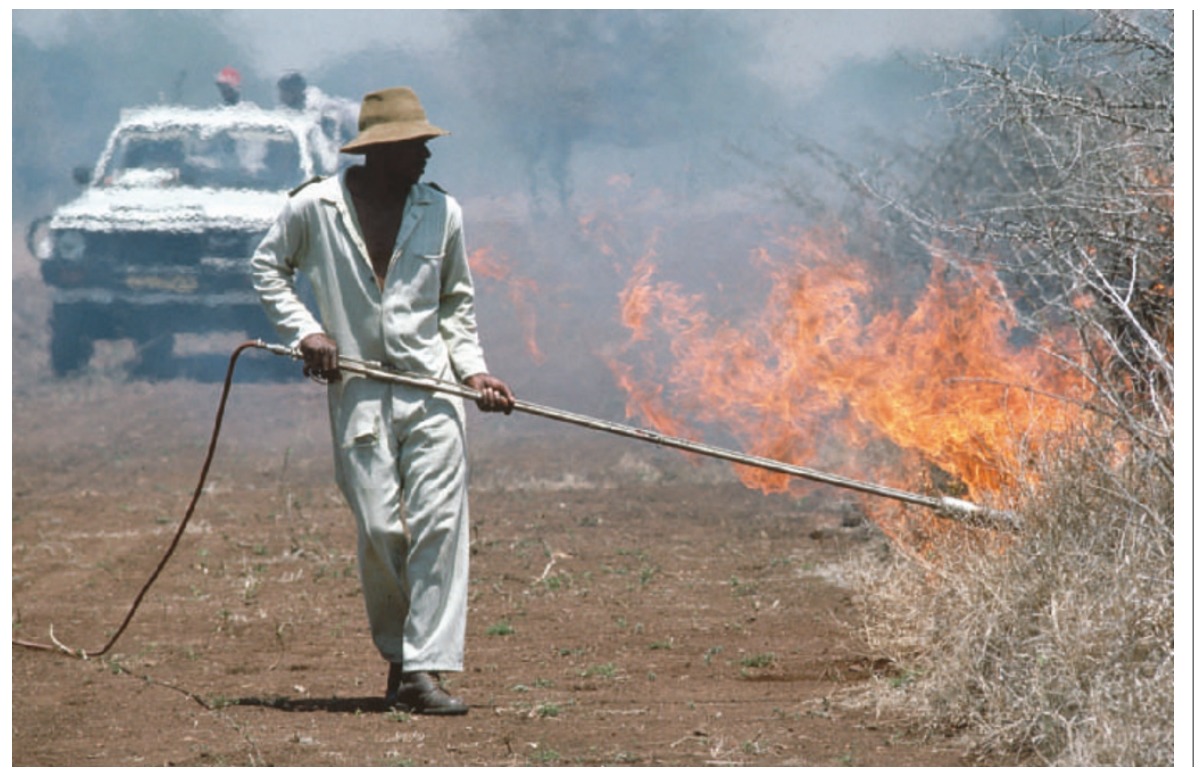

Burns unit: park rangers use fire to manage the ecology of South Africa's Kruger National Park.

heterogeneity in time and space, and their intention is to unravel the truism that heterogeneity underlies biodiversity and adaptive management. But there is also considerable value in the main body of the work, which is a fascinating compendium of observations on the ecology and management of the savanna biome.

Given South Africa's turbulent political past, the history of Kruger's management can be viewed against the backdrop of the changing socio-political context. Most of Africa's great national parks were established at a time when land use was allocated to suit the economic interests of colonial settlers. The new South Africa takes more seriously the land-rights conflicts that arise between conservation priorities and displaced or neighbouring farming communities. There are now many examples, as in other parts of Africa, of community-based approaches that allow local people some control over wildlife resources in a way that is more beneficial to conservation and sustainable use than strategies that dispossess local people and reduce their access to such resources.

At the outset, management interventions in Kruger were somewhat crude, such as the control of predators and fire, and the establishment of a network of water points, and were intended to increase the opportunities for viewing game. These have now given way to more subtle forms of adaptive management that attempt to recognize the complexities of natural processes within defined conservation objectives.

Fire policy provides a good illustration of the evolution of adaptive management. Fire was initially regarded as something to be avoided, but has since been seen as an integral part of natural savanna systems. Fire suppression then gave way to a policy of prescribed rotational burning in 1956. This command-and-control approach was abandoned in 1992, when it was realized that it had some negative effects and was a poor substitute for the processes by which natural fires drive and respond to vegetation heterogeneity. The next approach, which was intended to reproduce the patterns of frequency, season and intensity under which Kruger's biota evolved, allowed lightning fires to burn but suppressed anthropogenic fires. This led to the park's staff spending more time putting out fires than starting them. A mixed policy has now been adopted, in which all lightning fires are tolerated, and other fires are either started or tolerated only in areas that need to be burnt according to ecological criteria. A thorough-going state-dependent regime derived from the knowledge of how fires affect biodiversity was rejected as being too agricultural for a conservation area.

The ecological effects of establishing water points further illustrate the complexities of nature conservation and the law of unintended consequences. The provision of water was intended to allow game animals to spread into areas that were otherwise inaccessible to water-dependent species in the dry season, and to even out or homogenize vegetation use, but served to increase the number of wildebeest, zebra and their predators. Species that were less dependent on water, such as the roan antelope, now faced increased competition and heightened predation pressure from large carnivores attracted to the wildebeest and zebra. The roan antelope consequently suffered a precipitous decline in numbers, and is now endangered. In addition, the less dominant brown hyena has become extinct since the more dominant large carnivores became more common.

What, then, of heterogeneity? To those who reckon they have a common-sense understanding of heterogeneity, theoretical 